https://doi.org/10.25143/socr.13.2019.1.096-103

\title{
leskats delikta tiesībās
}

\author{
Dana Segale \\ Rïgas Stradiña universitāte, Latvija \\ danasegale@inbox.lv
}

\section{Kopsavilkums}

Rakstā tiek aplūkotas delikta tiesības, parādot paša jēdziena vēsturisko un mūsdienu piepildījumu, kā arī dodot plašāku ieskatu šajā jautājumā, proti, analizējot problēmas, kas saistītas ar aizsardzību pret nepamatotu personas tiesību aizskārumu, un sniedzot to risinājumus.

Pētījumā ir analizēts tiesību aizskāruma un atlīdzinājuma vērtējums, stingri ievērojot šādu aspektu: atlīdzinājums pēc savas būtības nevar tikt uzskatīts par iespēju piepelnīties, un to nedrīkst noteikt, vērtēšanā izmantojot kādu matemātisku formulu. Šeit arī apskatīta mūsdienās pastāvošā problēma (vai drīzāk vēlēšanās, kura ir pāraugusi problēmā) visu noteikt naudas izteiksmē.

Atslēgvārdi: delikta tiesības, apmierinājums, tiesību aizskārums.

\section{levads}

Jebkādu zinātnisko izpēti sākot, pamatoti ir jāpiekrīt Reimonda Hartmana (Raymond Hartman) atziṇai, ka zinātne nav kas vairāk kā formālas atskaites sistēmas piemērošana fenomena haosam. Veicot fenomena, šajā gadijjumā delikta tiesību, izpēti ir jāpatur prātā, ka fakti un skaidrojumi, kuri atklāj izzināmā fenomena saturu, ir tikai šì brīža aktuālās atskaites sistēmas apskats, kurš pakḷauts nemitīgai attīstībai un pārmaiṇām.

Šã pētījuma mērḳis ir aplūkot delikta tiesības, parādot paša jēdziena vēsturisko un mūsdienu piepildījumu, kā arī dodot plašāku ieskatu šajā jautājumā, proti, pievēršoties problēmām, kas saistìtas ar aizsardzību pret nepamatotu personas tiesību aizskārumu, un to risinājumiem.

Šā pētỉjuma gaitā tika izmantota teorētiskā pamatojuma metode, ar kuras palīdzību analizēta tiesību doktrīna, kā arī analītiskā metode. Tika salīdzinātas tiesību normas un dažādu autoru atziņas, kā arī salīdzināts tiesiskais regulējums normatīvo aktu un juridiskās literatūras aspektā, veikta analīze un apkopošana, lietojot aprakstošo metodi. 


\section{Jēdziena "delikts" vēsturiskais aspekts}

Pētot delikta tiesību izveidošanos, vispirms jāpievēršas romiešu tiesību analīzei delikta tiesību aspektā, jo tieši romiešu tiesībās tika ieviests šã fenomena skaidrojums un dots tam nosaukums, kas saglabājies līdz mūsdienām.

Romieši lietoja divus tiesību pārkāpumu apzīmējumus - crimen jeb noziegums un delietum jeb neatḷauta darbība. XII tabulu likumos ir paredzēti vairāki delikti. Visnopietnākais no tiem - iniuria jeb personas apdraudējums. Ja par šādu nodarījumu starp cietušo un uzbrucēju netika panākts izlīgums, tad rīkojās pēc taliona principa, t. i., "zobs pret zobu, acs pret aci”. Turpretī gadījumā, ja cietušajam bija lauzti kauli, pārsista galva vai ievainots vēders, XII tabulu likumi aizliedza rīkoties pēc taliona principa. Vainīgajam vajadzēja samaksāt cietušajam 300 asu; bet, ja cietušais bija vergs, tad par šādu pašu nodarījumu sods bija 150 asu (naudu san̦ēma verga īpašnieks). Par piekaušanu cietušajam pienācās 25 asis. [8]

Vēlākos laikos mainījās izpratne par neatḷautās darbības smaguma pakāpi, un atsevišḳi tika izdalītas neaț̣autās darbības ar smagām sekām. Tās uzskatỉja par noziegumiem, jo mainījās uzskats par dzīvības un veselības vērtību.

XII tabulu likumos bija paredzēti vēl citi delikti, mazāk nozīmīgi. Klasiskajā laikmetā romiešu tiesībās no noziedzīga nodarỉjuma zādzības (latīṇu valodā furtum) atsevišḳi tika nošķirta laupī̌sana (rapina). Delikti jeb tiesību pārkāpumi kā saistību izcelšanās pamats saglabājās arī Romas impērijas pēdējos gadsimtos. Tiesību pārkāpumiem, kurus joprojām sauca par iniuria, prētoriskajās tiesībās (ius praetorium) tika sašaurināts to saturs, atsakoties no taliona principa piemērošanas personas aizskāruma gadījumos. Prētoriskajās tiesībās bija paredzēts, ka par personas aizskārumu vajadzēja atlīdzināt ar likumā noteiktu naudas summu. [8]

Šis ieskats romiešu tiesībās l̦auj skaidri secināt, ka delikta regulējumā tika ietvertas konkrētas naudas summas par konkrētiem tiesību pārkāpumiem, un tas ir pretēji mūsdienu tiesu praksei un normatīvajam regulējumam. Mūsdienu izpratne par šo jautājumu labi ir redzama Augstākās tiesas apkopojumā sniegtajos skaidrojumos, proti, ka atlīdzības apmērs, piemēram, par morālo kaitējumu nosakāms katrā konkrētā gadījumā pēc tiesas ieskata, vadoties pēc taisnības apzinnas un vispārīgiem tiesību principiem. Jānem vērā, ka nepastāv vienota likme, lai noteiktu atlīdzības apmēru par morālo kaitējumu. To nosaka, n̦emot vērā morālā kaitējuma smagumu, raksturu, tā nodarīšanas apstākḷus un sekas, kā arī citus būtiskus apstākḷus. Piespriežamai summai jeb atlīdzinājumam jāpilda taisnīguma, prevencijas un samierināšanas funkcija. Atlīdzinājumam ne tikai jāsniedz mierinājums personai, kuras tiesības tikušas aizskartas, bet arī jāattur vainojamā persona no līdzīgu aizskārumu izdarīšanas nākotnē. Tādējādi atlīdzinājumam jābūt samērīgam. [11] 


\section{Atlīdzības apmēra noteikšanas izpratne}

Jautājums par atlīdzības apmēru vienmēr ir bijis aktuāls, un, izpētot judikatūru, nav pat manāma kāda konsekvence vai vienotas vadlīnijas apmierinājuma noteikšanā, vērtēšanā vai lielumā.

Tomēr, vērtējot jēdziena "delikts" mūsdienu izpratni, var atrast dažādus skaidrojumus, piemēram, tā ir neatbilstīga darbība vai bezdarbỉba, par kuru cietusī persona civilā procesā var prasìt zaudējumu piedziṇu, ja vien šĩ neatbilstīgā darbība nav tikai līguma pārkāpums. Civiltiesību pārkāpumu tiesības galvenokārt attiecas uz kompensāciju piešḳiršanu par personisku kaitējumu vai zaudējumiem, kas radušies nolaidības dēḷ. Taču tās aizsargā arī citas tiesības, piemēram, reputāciju, personisko brīvību, īpašumtiesības, īpašuma esību un komercintereses. Galvenais tiesiskās aizsardzības līdzeklis, kas tiek lietots šajos gadijjumos, ir zaudējumu piedziņa, taču dažkārt tiek sūtīti izpildraksti, lai novērstu kaitējumu atkārtošanos. [13]

Delikts ir jāsaprot arī kā civiltiesiska saistība, kura ir izveidojusies saskaṇā ar likumu, no personas subjektīvo tiesību aizskāruma ārpus līgumiskām attiecībām.

Civilprocesa likuma 1. panta pirmajā dạ̦ā noteikts, ka katrai fiziskai un juridiskai personai ir tiesības uz savu aizskarto vai apstrīdēto civilo tiesību vai ar likumu aizsargāto interešu aizsardzību tiesā [2].

Taču Civillikumā ietverts arī jēdziens "neatḷauta darbība". Tādējādi ir secināms, ka neatḷauta ir katra darbība, kura rada tiesību aizskārumu, kā arī tad, ja to rada bezdarbība, savukārt neatḷautā darbība un bezdarbība tiek iedalīta:

- līguma saistību nepildīšana jeb līgumattiecību pārkāpums, piemēram, nokavējums;

- delikts jeb ārpuslīgumisks pārkāpums, kas var izpausties personiskos veselības, dzīvības, goda, cieñas, brīvības vai mantiskos aizskārumos.

Neatḷautas darbības pretstats ir atḷauta (tiesiska) darbība, kas, pirmām kārtām, ir katram subjektam piederošo tiesību izlietošana. Par neațlautu darbību vai bezdarbību ir paredzēta civiltiesiskā atbildība, kura izpaužas aizskārēja personas, kas izdarījusi neatl̦autu darbību vai piẹ̦āvusi neatḷautu bezdarbību, pienākumā atlīdzināt cietušajam ar to radušos zaudējumus. [9]

Savukārt runājot par zaudējumiem, jāatzīmē, ka to atlīdzināšana ir galvenais aizskāruma apmierinājuma līdzeklis, kura mērḳis ir novērst sekas un atjaunot iepriekšējo stāvokli, kāds bijis pirms tiesību pārkāpuma. Pēc sava rakstura zaudējumi ir mantas samazinājums vai bojājums, kā arī peḷnas samazinājums un papildu izdevumi.

Civiltiesiskajai atbildībai un tai sekojošai zaudējumu atlīdzināšanai ir četri priekšnoteikumi:

- kādas personas prettiesiska rīcība (darbība vai bezdarbība);

- šìs personas vaina;

- zaudējumu esamība un to konkrēts apmērs;

- cēloniskais sakars starp prettiesisko rīcību un zaudējumiem. [9] 
Pastāvot šeit uzskaitītajiem priekšnoteikumiem, ir pamats runāt par zaudējumu atlīdzināšanu civiltiesiskā kārtībā. Lai izprastu delikta mūsdienīgo aspektu, kurš tiek atspoguḷots normatīvajā regulējumā, jāizvērtē, ar ko delikts atškiriras un kuras tā pazīmes ir tādas pašas kā normatīvajā regulējumā esošiem citiem jēdzieniem.

Delikta un saistības pārkāpuma gadījumā zaudējumu atlīdzības priekšnoteikumi atšķiras. Tāpēc (ar retiem izṇēmumiem) katram gadỉjumam ir savs prasījuma pamats un sava tiesību norma. Latvijā zaudējumu atlīdzības prasījuma pamats delikta gadījumā ir Civillikuma 1635. pants, bet saistības pārkāpuma gadījumā - Civillikuma 1779. pants. [14] Tādējādi ir pamats padziḷināti izpētīt Civillikuma 1635. pantu, kurā ir noteikts, ka katrs tiesību aizskārums, tas ir, katra pati par sevi neaț̣auta darbība, kuras rezultātā nodarīts kaitējums (arī morālais kaitējums), dod tiesību cietušajam prasìt apmierinājumu no aizskārēja, ciktāl viṇu par šo darbību var vainot. [1] Šã panta struktūra ir kā saistītu jēdzienu virtene, kā no viena apstākḷa vai fakta izrietošu seku rezultāts, kurš savukārt veido shēmu, proti, - ar neațautu darbïbu tiek nodarīts kaitējums, kas cietušajam dod tiesības prasīt apmierinājumu, tas savukārt ir ierobežots, ciktāl aizskārēju par šo darbību var vainot. Šì shēma ir kā virtene, kuras katra elementa esamība ir neizbēgama. Var arī secināt, ka Civillikuma 1635. pantā ietverti stingri priekšnoteikumi, proti, kaitējuma esamība, kura viennozīmīgi ir cēloniskā sakarā ar neatḷauto darbību vai bezdarbību, un, protams, priekšnoteikums ir arī pati neaț̣autā darbība vai bezdarbība. Tādējādi ir nodalāmi trīs priekšnoteikumi, kuri veido panta skeletu.

Izpētot šā panta jēgu un piepildījumu, ir vērts pievērsties Civillikuma komentāros dotajam skaidrojumam, ka tiesību aizskāruma gadījumā ir tiesības prasìt apmierinājumu, ka aizskārējam ir jādod apmierinājums. Civiltiesību galvenais uzdevums ir nodrošināt mantisko attiecību ekvivalenci. Taču civiltiesỉbas aizsargā arī personiskos labumus, ko nevar aizstāt ar naudu, tāpēc ne vienmēr ir pareizi runāt par zaudējumu atlīdzību. Šā iemesla dēl vispārināti tiek lietots plašākais apzīmējums "dot apmierinājumu". Termins "apmierinājums" ir jālieto arī tajos gadījumos, kuros strīds radies par mantas atdošanu, piemēram, patapinājumā, vai tajos gadījumos, kad kreditors vēlas, lai parādnieks izpilda noteiktu darbību vai atturas no darbības. [12]

Runājot par vainu un tās noteikšanu, jāuzsver, ka Civillikumā ietvertas daudzas vainas formas, piemēram, neuzmanība, kura savukārt var būt gan rupja, gan viegla, kā arī l̦auns nolūks, kurš savukārt ir katrs tǐšs kaitējums. Tomēr vainas noskaidrošanai ir nepieciešams arī cēloniskais sakars, kura konstatēšana un pakāpe ir svarīga vainas smaguma noteikšanā. Situācijas mēdz būt dažādas, un cēloṇsakarības pakāpes noteikšana ir allaž aktuāla. Piemēram var aplūkot šādu situāciju: divu uzṇēmumu sadarbība notiek saskañā ar noslēgtiem līgumiem, taču viena puse "SIA A" nepilda savas saistības, bet otra puse "SIA B" vēršas tiesā ar prasību, taču procesa laikā "SIA B" kḷūst maksātnespējīga, jo parādās vēl arī citi saistību nepildītāji. Te rodas jautājums, cik lielā mērā "SIA A" ir vainojama pie tā, ka "SIA B" iestājas maksātnespēja, vai tā iestātos arī gadījumā, ja saistības tiktu pildītas? Visdrīzāk, ka jā, taču daḷejja vaina vai cēloniskais sakars starp saistību nepildī̌̌anu un maksātnespējas iestāšanos nav noliedzams. 
Salīdzinājumam var minēt arī Eiropas deliktu tiesību principus, kuros tiek skaidrots, vai un kādā pakāpē kaitējumu var attiecināt uz aizskārēju, proti, ka tas ir atkarīgs no vairākiem faktoriem, to skaitā no kaitējuma paredzamības, personas saprātīguma, darbības laika, jo īpaši n,emot vērā laika vai telpas tuvumu starp kaitīgo darbību un tās sekām vai kaitējuma apmēru attiecībā pret normālu šādas darbības rezultātu. [10]

Arī Civillikuma komentāros sniegts skaidrojums par vainu apskatāmā jautājuma aspektā, proti, lai prasītu apmierinājumu, ir jānoskaidro, vai un ciktāl aizskārēju var vainot par viña darbību vai bezdarbību. Tomēr tiek stingri norādīts, ka civiltiesībās vainas definīcija nevar būt tāda, kā to atzīst krimināltiesībās. Vaina ir saistīta ar personas psihisko attieksmi, bet tā nav pati psihiskā attieksme vai tikai psihiskā attieksme. Civiltiesisko attiecību subjekti, kā zināms, ir arī juridiskas personas. Runāt par šo personu psihisko attieksmi vispār nav logiiski, jo psihe var piemist tikai fiziskām personām. Turklāt l̦auna nolūka traktējums stipri atškiras no neuzmanības traktējuma, kas savukārt apgrūtina vienotas vainas definīcijas izstrādāšanu. [12]

No minētā var secināt, ka tieši nolūks un neuzmanība var veidot vainu, taču nedrīkst aizmirst, ka paša jēdziena "vaina" izpratne administratīvajās tiesībās, krimināltiesībās un civiltiesībās krasi atšḳiras.

Lai gūtu plašāku un dzị̣āku apskatāmā jautājuma izpratni, ir jāanalizē arī judikatūrā pastāvošie viedokḷi un nostājas. Latvija Republikas Augstākās tiesas tiesu prakses apkopojumā norādīts, ka morālais kaitējums ir personas ciešanas, sāpes un pārdzīvojumi, ko nav iespējams tieši novērtēt. Pārciestā sekas nav iespējams aizstāt ar naudu, taču, sniedzot cietušajai personai atbilstīgu atlīdzinājumu naudas izteiksmē, ir iespējams sniegt viṇai zināmu gandarījumu un tādējādi mazināt ciešanas un sāpes. Tā kā morālais kaitējums ir aizskāruma negatĩvās sekas, tiesai pēc prettiesiskas rīcības fakta visupirms ir jākonstatē morālā kaitējuma esamība un tikai pēc tam jāvērtē atlīdzības apmērs. [11]

Jāṇem vērā, ka pēc būtības zaudējumu atlīdzība Latvijas tiesībās primāri tiek regulēta ar Latvijas Republikas Satversmes 92. panta trešo teikumu, proti, nepamatota tiesību aizskāruma gadījumā ikvienam ir tiesības uz atbilstīgu atlīdzinājumu [3]. Taču nedrīkst aizmirst, ka ir jānošḳir atlīdzības prasības pret privātpersonām civilprocesa un kriminālprocesa ietvaros un atlīdzības prasības pret valsti, kuras savukārt tiek regulētas administratīvā procesa ietvaros. Nav iespējams nošḳirt pašu tiesību aizskārumu un atlīdzinājumu, jo nav noteikti atlīdzības standarti, un rodas jautājums par atlīdzības atbilstību. Jāatzīst, ka atbilstīga atlīdzinājuma problemātika bieži tiek analizēta judikatūrā, un daḷeji jāpiekrīt Latvijas Republikas Augstākās tiesas nostājai, ka ir noškirama virkne principu, kas ir jāievēro atlīdzinājuma noteikšanā. Lai atlīdzinājums būtu atbilstīgs Latvijas Republikas Satversmes 92. panta izpratnē, tam ir jābūt efektīvam tiesiskās aizsardzības līdzeklim [5]. Jēdziens "atbilstīgs atlīdzinājums" nozìmē, ka atlīdzinājumam ir jābūt taisnīgam. Atlīdzinājumam ir jāsniedz gandarījums personai, kuras tiesības ir tikušas aizskartas [7]. Tādējādi atlīdzinājums demokrātiskā un tiesiskā valstī nedrīkst būt nesamērīgi mazs [6]. Tomēr apskatot "atbilstīga atlīdzinājuma" jēdzienu un Latvijas Republikas Satversmes 92. panta trešo teikumu, var secināt, ka atbilstīga atlīdzinājuma izpratne parasti tiek 
skatīta finansiālā aspektā, t. i., cik liela naudas summa ir atzīstama par pietiekošu apmierinājumu. Ir vērts pievērst uzmanību tam, ka jēdzienam "atbilstīgs atlīdzinājums" nedrīkst pieškirt tikai mantisku raksturu, jo sasniegt taisnīgumu un sniegt gandarijumu jeb apmierinājumu personai, kuras tiesības ir aizskartas, var arī nemateriālā veidā, piemēram, publiska atvainošanās var sniegt apmierinājumu.

Tiesību aizskārums un atlīdzinājums nevar tikt uzskatīts par iespēju piepelnīties, un to nedrīkst noteikt, vērtēšanā izmantojot kādu matemātisku formulu. Ja romiešu tiesībās bija pien,emts konkrēts mantisks atlīdzinājums par konkrētu tiesību pārkāpumu un šāda pieeja neradīja mulsumu, tad mūsdienās tiesību normas nevar tikt matemātiski pamatotas. Līdzịga nostāja ir pausta vairākos Eiropas Cilvēktiesību tiesas nolēmumos, kuros tiek minēts, ka taisnīga atlīdzinājuma noteikšanā tiesa ir nošḳīrusi tos gadījumus, kuros iesniedzējs guvis fizisku vai psiholoǵisku traumu, mokas, nemieru, neapmierinātību, piedzīvojis sāpes un ciešanas, netaisnības vai pazemojuma sajūtu, ilgstošu neskaidrību, dzīves izpostî̌̌anu vai arī patiesu iespēju zudumu, no gadījumiem, kuros iesniedzējam nodarīts kaitējums mazākā mērogā, un tādēḷ publisks atzinums dalībvalstij saistošā spriedumā pats par sevi tiek uzskatìts par spēcīgu kompensācijas veidu [4]. Proti, jau pati par sevi apstākḷa, ar kuru tikušas aizskartas tiesības, atzīšana par tiesību normām neatbilstošu vai spēkā neesošu sniedz pietiekošu apmierinājumu, dodot pamatu arī citiem sabiedrības locekḷiem justies pasargātākiem no tiesību pārkāpumiem, nekā bija iepriekš. Taču gadījumos, kuros tiesību pārkāpuma apmierinājums tiek sniegts naudas izteiksmē, netiek skatìta situācija plašāk, vērtējot tiesību aizskarošo procesu atbilstību un iespēju tos labot, un nepiel̦aut turpmāk. Rodas situācija, ka nolēmums l̦auj skaidri redzēt robežu, kas vēlmi gūt kādu materiālu labumu un gūt apmierinājumu par tiesību pārkāpumu noškịir no vēlmes saņemt atziņu par notikušo un apliecinājumu, ka tiesības tikušas aizskartas. Materiālā apmierinājuma guvums nevar būt vienīgā sabiedrības vērtību skala.

“Tiesiskās aizsardzības efektivitāte" un "atbilstīgs atlīdzinājums", kā arī daudzi citi jēdzieni, kuri pēc būtības tiek haotiski minēti, piemēram, judikatūrā, bieži vien nav jēdzieni, kuri pārklājās. Tiesības var būt efektīvi aizsargātas, bet rodas jautājums, vai to aizsardzība ir taisnīga, samērīga un visbeidzot - atbilstīga? Atbildot uz šiem jautājumiem, parādās viens no sarežgî̀tākajiem apskatāmā temata aspektiem, proti, kā pierādīt tiesību aizskāruma apmēru un noteikt ekvivalentu atlīdzinājumu, kā izvēlēties atlīdzinājuma līdzekli un veidu, kurš sniegs paredzamo apmierinājumu? Šie jautājumi judikatūrā bieži vien tiek atstāti bez atbildes. Kaut arī juridiskajā literatūrā ir minēts, ka izšḳirošs ir tieši atlīdzinājuma līdzeklis, kurš nodrošina efektīvu tiesisko aizsardzỉbu konkrētajam tiesību aizskārumam, tomēr atlīdzinājums biežāk tiek saprasts kā novērtējums naudas izteiksmē. Taču neapšaubāmi atšķirīga un pat nesalīdzināma ir katras personas izpratne par naudas apmēru, kurš rada apmierinājumu, jo tas ir samērīgs ar katras personas dzīves līmeni, prasībām un izpratni. Šie aspekti ir paḳ̣auti arī vecumam un izglìīibas līmenim - jauns cilvēks savas karjeras sākumā ir mazāk prasīgs, persona brieduma gados ar labiem ienākumiem citādāk vērtē savu tiesību ierobežojumu un visbeidzot personai cienījamā vecumā ir sava, ḷoti atšḳirīga kritēriju skala un prasības. 


\section{Secinājumi}

Izpratne par atbilstīgu atlīdzinājumu kā tikai finansiāli piepildītu jēdzienu ir pārāk šaura un liek domāt par analogiju ar prētoriskām tiesībām, kurās par konkrētu aizskārumu tika paredzēts atlīdzinājums ar likumā noteiktu naudas summu.

Atš̌kirīibā no Senās Romas mūsdienu sabiedrībā nav iespējama doma, ka katra aizskāruma scenārijs ir iepriekš aprēḳināts naudas izteiksmē. Lai arī cik produktīvi būtu šāda veida strīdu risināšanas modelii, tomēr tie izslēgtu iespēju individuāli vērtēt katru gadïjumu. Taču nevar arī neminēt to, ka katra gadỉjuma atšķirīga vērtēšana atstāj vietu nevienlīdzībai. Proti, ja persona zināšanu trūkuma dēl nav informēta par iespējām, tā nevar tās izmantot pilnā apmērā vai pat daḷejii, savukārt cita persona spēj gan finansiāli, gan arī zināšanu līmenī izkonkurēt citus, tādējādi gūstot lielākus panākumus savu tiesību aizsardzībā.

\section{Insight into Tort Law}

\section{Abstract}

The aim of the article is to provide an insight into the Tort Law, which will reveal historical and contemporary fulfillment of the notion itself, as well as to present an insight into a broader issue of the problem of protection of unjustified infringement of the rights of a person and their solutions.

Keywords: Tort Law, satisfaction, infringement of law.

\section{Avoti un literatūra}

\section{Tiesību akti}

1. Civillikums: Latvijas Republikas likums: pieṇemts 28.01.1937. un stājās spēkā 01.09.1992. Valdỉbas Vēstnesis. 41, 20.02.1937. Iegūts no: https://likumi.lv/doc.php?id=225418 [sk. 01.07.2019.].

2. Civilprocesa likums: Latvijas Republikas likums: pieṇemts 14.10.1998. un stājās spēkā 01.03.1999. Latvijas Vēstnesis. 326/330(1387/1391), 03.11.1998. Iegūts no: https://likumi.lv/doc.php?id=50500 [sk. 01.07.2019.].

3. Latvijas Republikas Satversme: Latvijas valsts likums: pieṇemta 15.02.1922. un stājās spēkā 07.11.1922. Latvijas Vēstnesis. 43, 01.07.1993. Iegūts no: https://likumi.lv/doc.php?id=57980 [sk. 01.07.2019.].

\section{Tiesu prakse}

4. European Court of Human Rights Case of Varnava and Others v. Turkey. 18 September 2009. Strasbourg (Applications nos. 16064/90, 16065/90, 16066/90, 16068/90, 16069/90, 16070/90, 16071/90, 16072/90 and 16073/90). Iegūts no: https://hudoc.echr.coe.int/eng\# ‘"appno":["16064. /90"],"itemid":[“001-94162"]\} [sk.01.07.2019.]. 
5. Latvijas Republikas Augstākās tiesas Senāta Administratīvo lietu departamenta 2007. gada 1. marta spriedums lietā Nr. SKA-54/2007, 8. punkts.

6. Latvijas Republikas Augstākās tiesas Senāta Administratīvo lietu departamenta 2010. gada 16. februāra spriedums lietā Nr. SKA-104/2010, 18. punkts.

7. Latvijas Republikas Augstākās tiesas Senāta Administratīvo lietu departamenta 2011. gada 18. februāra spriedums lietā Nr. SKA-161/2011, 16. punkts.

\section{Literatūra}

8. Birziṇa, L. 2006. Romiešu tiesības. 2. izd. Rìga.

9. Džugleja, T. 2011.Tiesību pamati: Mācību lìdzeklis. Rīga: Rīgas Tirdzniecības tehnikums.

10. European Group on Tort Law: Principles of European Tort Law. Universitat de Girona. 2005. Iegūts no: http://civil.udg.edu/php/biblioteca/items/283/PETL.pdf [sk.01.07.2019.].

11. Latvijas Republikas Augstākā tiesa: Morālā kaitējuma atlīdzināšana civillietās: Tiesu prakses apkopojums. Rīga, 2014.

12. Latvijas Republikas Civillikuma komentāri: 4. d.: Saistību tiesības (1401.-2400. p.). Zin. red. K. Torgāns. Rīga: Mans īpašums, 1998.

13. Oxford Dictionary of Law. Oxford Reference. 2009. Iegūts no: doi:

14. 10.1093/acref/9780199551248.001.0001 [sk.01.07.2019.].

15. Strazdiṇš, G̣. Vispārējais zaudējumu atlīdzības prasījuma pamats delikta un saistības pārkāpuma gadijjumā. Jurista Vārds. 6(1012), 06.02.2018. 